\title{
A Review of Reading Race: Aboriginality in Australian Children's Literature
}

\author{
Roderick McGillis
}

Clare Bradford. Reading Race: Aboriginality in Australian Children's Literature. Carlton South: Vic.: Melbourne UP, 2001. 283 pp. ISBN 052284954-7

The Cambridge Guide to Children's Books in English (2001) contains a brief entry on Markoosie, and I quote it here:

Markoosie 1942. Canadian (Eskimo) writer, Markoosic is the author of Harpoon of the Hunter (1970), the first novel to be published in Eskimo. It was originally published in a syllabic-symbol system invented by missionaries in the publication Inuttittut (Eskimo Way); it was then translated into English. The novel concerns the inititation of an Eskimo boy, Kamik, into the harsh life of the hunters of the Arctic Circle. Stylistically, the novel has many of the rhythms of the oral tradition from which it came; at the same time, like much modern fiction, it enters into the inner lives of its characters. (p.466)

$\mathrm{W}$ There to begin? Well, in the first place 'Eskimo' is a word not much used any more in Canada, although it is apparently common in Alaska. The Native peoples of Northern Canada and Greenland are most often referred to as Inuit, and 'Eskimo' can carry offence to some people. 'Inuit' refers to three or more Arctic aboriginal persons, and it echoes from the name of the magazine in which Harpoon of the Hunter first appeared, Inutituut (not Intuttittut, as it appears in the Cambridge Guide). The Guide has a parenthetical translation of the word it prints as Inuttittut (Eskimo $W a y)$. The word 'Inuttituut' refers to the language spoken by certain Arctic people, and it more often than not appears in the Roman alphabet as 'Inuktitut' or 'Inukitut.' 'Inuk' refers to one Inuit person, and therefore the word 'Inuk-titut' means 'in the way of an Inuk'. Inuttituut, then, refers to a language, but not just to a language; it also refers to a way of life, a way of speaking, acting, thinking, and living. The Guide's 'Eskimo Way' remains vague, simple, and insufficient to render clearly what the Inuit word means.

The Guide notes that Harpoon of the Hunter is the 'first novel to be published by an Eskimo.' In fact, the book is the first original novel by a Canadian Native of any ethnicity to appear, and Markoosie initially wrote it in a syllabic system. The phrase the Guide uses, 'syllabic- symbol system,' strikes me as unnecessarily condescending in its needless reference to 'symbol'.

The description of the novel as depicting a rite of passage and the comparison with 'much modern fiction' ignore the book's resistance to Eurocentric narrative patterns. Harpoon of the Hunter is completely unlike much modern fiction, and it depicts not so much a rite of passage as a blunt confrontation of the end of a way of life, the death of a culture brought on by precisely those Eurocentric ways of being into which the Guide so slyly attempts to assimilate Markoosie's novel. And finally, the assertion that the novel 'enters into the inner lives of its characters' may have some validity, but not in any conventional sense. Mostly, the focus is on Kamik and his growing awareness of the futility of the survival struggle. This book is starkly unlike the great majority of books published for young readers; the death by suicide of the main character needs to shock readers for cultural and political reasons rather than for psychological or sociological reasons. Even the most uncompromising of Young Adult books rarely achieves the cultural self-consciousness and honesty of Harpoon of the Hunter.

But why do I begin with Markoosie? My simple motive is this: the treatment of Markoosie in the Cambridge Guide is an indication that the kind of racial blindness and acceptance of cliche that Clare Bradford identifies in her book Reading Race: Aboriginality in Australian Children's Literature as alive and flourishing and not restricted to the presentation of Aboriginality in Australian books for the young. Her focus is mostly on fiction and picturebooks for the young, but the myopic attitudes which she identifies are also available in writing about literature for the young. The Cambridge Guide serves up more examples than the one I have given. Just check the entry on Patricia Wrightson, or the absence in the entry on publishers and publishing of Aboriginal publishers in Australia or Canada or the U.S. or anywhere else. Or note how the entry on Phillip Gwynne makes no mention of Aboriginality and passes over Deadly Unna? (1998) to give more space to The Worst Team Ever (1999). Or note that Dick Roughsey appears listed alphabetically, but the only mention of his work is in conjunction with Percy 
Trezise and this mention appears only in the entry on Trezise. Absent altogether are the likes of Elsie Jones, Yvonne Edwards, Brenda Day, Pat Lowe, Melissa Lucashenko, Jimmy Pike. Jackie French has an entry, but it contains no mention of Walking the Boundaries (1993). In passing, I note that Australian books and writers and illustrators have or appear in two hundred and six entries in this Guide. I could go on, but the point is that writing by and about Aboriginal people remains marginalised and slighted. For this reason, if for no other, Clare Bradford's study is of crucial importance.

I say, 'if for no other', and of course Bradford's book is important for other reasons. And I will come to these. But first I must provide an autobiographical note, just as Bradford does near the beginning of her book. I am a Canadian writing about Australian literature, and, what's worse, I am a white Anglo-Saxon male Canadian writing about a book written by a New Zealand-born woman whose racial background I really do not know, who is writing about Aboriginality in Australian children's literature. In other words, I write about experiences I have never had and a topic which I know only from a distance, and I do not wish to fall back on formalist and positivist arguments in order to avoid the politics of discussing matters of race. One of the salutory results of reading Bradford's study is the necessity of self reflection that this book demands.

Let me give you an example. I have admired the work of Patricia Wrightson for many years. Her prose impresses me with its intensity and lyricism, its epic register and rhetorical control. It is persuasive. I illustrate with a passage, part of which Bradford quotes, from The Nargun and the Stars:

At the bottom the water fell, with a sound-andecho like guitar strings, into a pool that spanned the gorge. Behind thispool-behind a bead-curtain of falling water-cut broad and low into the base of the cliff was the archway of a cave. This was the ancient den of the Nargun. Here it had lain while eagles learnt to fly and gum-trees to blossom; while stars exploded and planets whecled and the earth settled; while the cave opened; while dripping water hollowed a pool from rock and filled it, and drop by drop built crystal columns before the cave. And all this while the Nargun slept.

(1973, p.7)

This short paragraph shows consummate control. The alliterative effect throughout draws attention to the language as material; language too creates shapes and patterns just as falling water and time do. Alliteration also reflects the falling water, descending in two showers: 1 g-l-g-s-l-s-g and b-b-b-c-c-b-b-c-c. Wrightson's use of anaphora and polysyndeton creates the effect of accumulation, extension, development through space and time. The conscious attention to sentence length suggests the peristaltic movement of time itself. The sense of an animistic force at work in the evolving of nature is clear to me here. In other words, Wrightson's prose nicely folds its content into its form. For me, Wrightson's mastery of her material (i.e. language) allowed me to overlook her use of the materiality of others.

Her use of the materiality of others is precisely what interests Bradford. She notices that the language of this same passage is conventional; it is the kind of language ('register') that signals mythic import and religiosity in modern fantasy. She is right. This 'register' might also be located in writing that traces its lineage through High Romanticism back through the English and Classical epic tradition. It turns up in twentieth-century writers such as William Faulkner and Cormac McCarthy or Alan Garner and Jill Paton Walsh. It is neither confined to fantasy nor to children's literature. As Bradford perceptively shows, Wrightson's considerable mastery over this language of epic in the western tradition accomplishes an act of appropration and elision when she chooses to use it in presenting material from a culture outside the western tradition. As she says, The Nargun and the Stars treats 'the land as imbued with an uncanny presence, and enact[s] an elision of Aboriginality'. In this novel, the main character, the white boy Simon, serves as 'custodian of a mythical being detached from Aboriginality' (1973, pp. 53-54). As Bradford convincingly demonstrates, not 
only through a reading of The Nargun and the Stars but also through an examination of Wrightson's non fictional explanations of her own work, what Wrightson's writing accomplishes is an assimilation of Aboriginal ways of thinking into western ways of writing and thinking. While ostensibly championing Aboriginal culture, Wrightson effaces it. The force of Bradford's reading, then, effects a necessary revaluation of formalist readings that will inevitably find much to praise in Wrightson's prose. Formalism divorced from cultural praxis blinds when it ought to enlighten.

I come back to the crucial importance of Bradford's book: it provides evidence of the continuing cultural practice of effacement of Aboriginality. The eight chapters take up a variety of subjects that allow Bradford to move from earlier writing for children to contemporary works. She deals with colonial discourse in a chapter that discusses school text books from 1900 to 1960, Richard Rowe's The Boy in the Bush (1869), Mary Grant Bruce's Billabong books, which appeared from 1910 to 1942, and Gary Crew's Strange Objects (1991). Religious discourses are the subject of chapter two. Here Bradford examines a range of texts from Wrightson's The Nargun and the Stars to work by Aboriginal and non-Aboriginal writers and illustrators. The reading here covers many texts and several subjects. Bradford shows how the discourses of Christianity, like New Age discourses and discourse I would call 'romantic' (this includes the language of environmental awareness as well as language sensitive to the instinctual virtues of women and children), tend either to assimilate Aboriginal sacredness or to sentimentalize Aboriginal religious sensitivity. The connection of religion with tropes of children and women neatly segues into Bradford's third chapter on gender and race in children's books. The discussion deals with female-authored and male-authored books, a close reading of John Wilson's Lori (1989), Aboriginal masculinity in colonial texts, and gender representations in contemporary books. Feminist and postcolonial discourses juxtapose colonial and racist discourses.

Chapter 4 takes up the topic of voice, specifically the ways in which non-Aboriginal writers speak for
Aboriginal peoples. Most effective is Bradford's identification of Aboriginalism, the apparent sympathy of non-Aboriginal people for Aboriginal peoples that manifests itself in a paternalistic and appropriating attitude. As Bradford puts it, 'the warm glow of Aboriginalism conceals its appropriating and controlling strategies' (p.110). Texts she considers here include Kate Langloh Parker's Australian Legendary Tales (1896), Marsden and Tan's The Rabbits (1998), Hashmi and Marshall's You and Me, Murrawee (1998), Whitcombe's Pictorial Story of Australia for Young Australians (1930s), and Rex Ingamell's Aranda Boy (1952). This chapter concludes with another look at Patricia Wrightson to illustrate 'the consistency of her approach and its reliance on Aboriginalist ideologies' (p.127). The texts Bradford examines here span Wrightson's writing career: The Crooked Snake (1955) and Shadows of Time (1994). She also comments on The Wrightson List (1998), a glossary of some 200 Aboriginal spirit figures. Wrightson's assumption of authority over a body of knowledge she can only come to as an outsider, and her readiness to speak for those eminently capable and willing to speak for themselves, because 'in folklore cultures don't meet at all but flow in and out of each other like seas' (qtd in Bradford p.128), is a clear instance of Aboriginalism. Once again in this chapter we see that attitudes we might like to think belong to the past have a tenacity that keeps them alive in the present, although in less obvious ways.

I'll indulge in a brief illustration of that last point. Two recent commentaries on Wrightson's fiction clearly show Aboriginalism at work. In Deconstructing the Hero: Literary Theory and Children's Literature (1997), a work that is sensitive to the continuing and problematic valuation of western presentations of heroism, Margery Hourihan remarks that Wrightson, in The Nargun and the Stars, 'makes sensitive use of material from Aboriginal mythology to dramatize an encounter between a white child and the ancient land' (p.27). She asserts that Simon, the book's protagonist, must learn to understand Aboriginal Dreamtime beforehe can find his own identity. This short treatment of Wrightson's novel leaves the reader with the impression that Wrightson is fully sensitive 
to the rights of Aboriginal peoples. Even more troubling is the examination of Wrightson's work in Martha Westwater's Giant Despair Meets Hopeful: Kristevan Readings in Adolescent Fiction (2000). Westwater's reading of The Nargun and the Stars rests on her assertion that Wrightson's 'Aborigine serves as a metaphor for the universal adolescent' (p.22). Nowhere in Westwater's reading of Wrightson does the irony of this statement make itself clear to her; nowhere does she twig to the irony in her word 'serves.' Instead we learn that Wrightson 'has grasped the essential semiotic nature of the Aborigines' culture' (p.25), and that she has given 'her Nargun intense credibility' (p.27, my italics), and so on.

Chapters 5 and 6 range over different kinds of texts to discuss 'who can speak' about Aboriginality and indigenous voices in children's literature. I do a disservice to Bradford to shrink these two chapters into a one paragraph description; she discusses the critical reception of books that represent Aboriginality, as well as children's books themselves. Bradford remarks that reviews of books such as Marsden and Tan's The Rabbits 'generally elide reference to the how of discourse, reducing texts to clusters of ideas, much like those exercises from textbooks of the past which require students to describe the theme and content of novels, as though the significance of texts are reducibie to such summary treatment' (p.138). I fear my own approach here is reductive. Essentially, the cluster of ideas I identify in Reading Race have to do with Aboriginalism, appropriation and silencing, and discourses as power manæuvres. Chapters 7 and 8 deal with books that might offer reconciliation and hope for tolerance and understanding. But the general impression a reader of Bradford's book will take from his or her reading is that Aboriginal voices are still heard less than they might be. I'll return to this shortly.

But before I take up that last point, I return to the "how of discourse,' and to a reason to value Reading Race other than for the general drift of this book. Bradford not only provides, in general ways, a genuinely moving argument concerning the continuing paternalistic attitude toward Aboriginal peoples; she also proves to be an intensely effective close reader. She brings the formalist's training to a postcolonial reading practice. I'll offer just one example. In Chapter 2, Bradford examines the treatment of the Aboriginal sacred in Bill Scott's Darkness Under the Hills (1980). Here, as elsewhere in Reading Race, she demonstrates the kind of reading we used to think of as 'close reading,' noting Scott's use of doublets, elevated expressions, 'metonymic references,' a 'reversal of pronoun and auxiliary.' She also notices 'discursive echoes' to biblical tropes that have the effect of subsuming Aboriginal sacredness 'into Western conceptual and ideological frameworks' (pp.67-68). Throughout Reading Race. Bradford demonstrates acumen in reading both fiction and critical prose, and in reading illustrations. For an example of her ability to read the intricacies of visual representation, see her discussion of an illustration from Richard Rowe's The Boy in the Bush (pp.98-99) or the icon, 'designed by Bronwyn Bancroft,' appearing at the head of each chapter in Jackie French's Walking the Boundaries (pp.201-202). Bradford's readings convince precisely because she is such a good close reader.

Now I return to my point that Aboriginal voices remain less often heard than they should be. Bradford's discussion of two responses to Susan Jeffers's American picturebook, Brother Eagle, Sister Sky (199l) alludes to Jon Stott's analysis of the book's failings in his book, Native Americans in Children's Literature (1995) and the response to Stott by Paula Giese on her website, 'Big Baddies (NatAm Brand) for Kids.' Bradford points out how Giese's response helps us to see more clearly than we otherwise might that Stott's work 'discloses how unexamined and naturalised ideologies insert themselves into critical discourse' (p.136). One of Giese's points is that Stott provides valuable criticism of Jeffers's book, but he does so without acknowledging the Native voices who preceded him in criticizing this book. Stott's failure to cite previous commentators leaves a reader of Stott's book assuming that he has discovered the errors and misapplications in Jeffers's work himself and that he now speaks for, rather than along with, Native people. I suspect most of us who write about cultural material we know from the outside are guilty of such unexamined ideological work. Take the beginning of this review, for example. There I discuss a reference book's entry on the 
Inuit writer and politician, Markoosie. What I fail to indicate is that much of my understanding of this book derives from Paula Giese's review of Stott's Native Americans in Children's Literature. Among other things, Giese notes that Kamik, the main character in Harpoon of the Hunter,

killed himself because he does not want to live in the diminished and corrupt world the invaders have imposed on his people, and he sees no way he can oppose that invasion. In remarking that 'Inuit stories do not follow western cultural patterns, 'Stott is simply concealing (and helping white youth to conceal) that this ston' is about invasion, destruction, exploitation, and Kamik's final rejection of the remaining diminished life. This is a realistic ston', one individually-focussed story on the destruction of a people. Suicide is the greatest cause of death among Indian teenagers. whose suicide rate exceeds that of every other race.

Giese argues that describing Harpoon of the Hunter as unlike conventional western plots is a ploy designed to deflect attention from the stark realism of the story, its direct confrontation with cultural destruction perpetrated upon one culture by another.

My explanation of the words 'Inuk' and 'Inuktitut' derives from my scrutiny of several web sites, some maintained by the Canadian government and some by Native groups. Most specifically, I used a site owned by an Inuit company, Tununiq Travel and Adventure, which has information on the Inuktitut language which 1 found useful. Obviously, much information is available for those of us outside Inuit culture, but accessing and absorbing this information is a time-consuming activity. The best many of us can do is acknowledge the reliance we must have on Native sources of information to strengthen our comments on Native cultures. We need to speak sparingly and without the assumption of authority.

But white people who care about matters of race ought not to defer completely to the voices of the other and leave off speaking themselves about race. Yes, we ought to defer to the voices of those who know what we do not or cannot know, but we also ought to continue to speak about faimess, justice, and tolerance and to speak out when we notice unfairness, injustice, and intolerance. To write a book such as Reading Race is largely to work toward self awarenesss. In other words, Reading Race is a book as much for Clare Bradford as for her readers. Clearly, she has gained a measure of self awareness through the researching and writing of this book. I can only hope that I, along with the many many other readers this book deserves, gain a similar measure of self awareness. Such self awareness comes with difficulty, but it also brings great benefit. 


\section{REFERENCES}

Bradford, Clare (2001) Reading Race: Aboriginality in Australian Children's Literature. Carlton South Vic, Melbourne UP.

Giese, Paula (2002) 'Adult Reading Level', <http:/www.kstrom.net/isk/books/adult/ stott.html > accessed May 19..-

Hourihan, Margery (1997) Deconstructing the Hero: Literary Theory and Children's Literature. London and New York, Routledge.

Tununiq Travel and Adventure (2002) accessed May 19.

Watson, Victor (200I) The Cambridge Guide to Children's Books in English. Cambridge, Cambridge UP.

Westwater, Martha (2000) Giant Despair Meets Hopeful: Kristevan Readings in Adolescent Fiction. Edmonton, University of Alberta Press.

Wrightson, Patricia (1974) [1973] The Nargun and the Stars. London, Hutchinson.

\section{BIOGRAPHICAL NOTE}

Roderick McGillis is from the University of Calgary, Canada. His scholarly writing and reviewing of children's literature is well known internationally. Two of his latest works are Voices of the Other: Children's Literature and the Postcolonial Context (Garland, 1999) and Children's Literature and the Fin de Siècle (Greenwood Press, 2002)

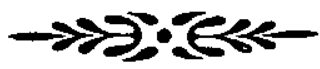

